Ковтун, Альбіна. «Релігійна лексика у західноукраїнських ЗМІ в період Другої світової війни». Лінгвостилістичні студії, вип. 14, 2021, с. 71-88.

Kovtun, Albina. "Religious Vocabulary in Western Ukrainian Nationalist Media During World War II". Linguostylistic Studies, iss. 14, 2021, pp. 71-88.

Удк 811.161.2'0'373:2

https://doi.org/10.29038/2413-0923-2021-14-71-88

\title{
РЕЛІГІЙНА ЛЕКСИКА У ЗАХІДНОУКРАЇНСЬКИХ ЗМІ В ПЕРІОД ДРУГОЇ СВІТОВОЇ ВІЙНИ
}

\author{
Альбіна Ковтун \\ Чернівецький національний університет імені Юрія Федьковича, \\ Чернівці, Україна
}

У статті з'ясовано специфіку функціонування релігійної лексики у ЗМІ

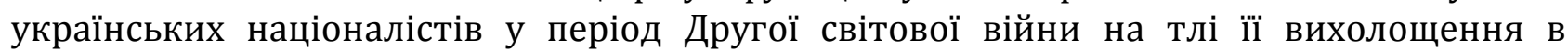
тогочасних радянських газетах. Автор дійшов висновку, що специфічною ознакою виходу релігійної лексики за межі традиційного у ЗМІ ОУН було формування з її участю іронійно-сатиричних перифразних одиниць, спрямованих проти сталінської політики. Друкований орган радянської влади відверто уникав релігійних тем, і лише 1945 року вийшла розлога замовна стаття «3 хрестом чи з ножем?» В. Росовича (Я. Галана), у якій автор активно послуговувався біблійними алюзіями, дошкульними художніми засобами, фразеологізмами тощо із зарезервованими для релігійної сфери лексемами. Соціальне замовлення «словесного огиджування» образу А. Шептицького та всієї Української греко-католицької церкви працювало на «вивітрення» релігійної семантики.

Ключові слова: семантика, фразеологізм, бібліїзм, біблійний афоризм, біблійна алюзія, художній засіб.

\section{RELIGIOUS VOCABULARY IN WESTERN UKRAINIAN NATIONALIST MEDIA DURING WORLD WAR II}

\author{
Albina Kovtun \\ Yuriy Fedkovych Chernivtsi National University, Chernivtsi, Ukraine
}

Modern linguists do extensive research on the functioning of religious vocabulary during the Soviet period, but the material of Western Ukrainian newspaper speech of this time has not yet been the object of linguistic study. It determines the relevance of this study. Its purose is to reveal the specifics of the preservation and development of the semantics of religious lexemes in the media of nationalists in Western Ukraine during World War II against the background of their lost-of-meaning in the Soviet newspapers of that time.

As a result of the analysis of the printed Western Ukrainian mass media of 1939-1945 (Ostanni visti, Volia Pokuttia, Vilne Slovo, Holos Pidkarpattia, Ukrainski visti, Rohatymske slovo, Samostiina Ukraina, Stanislavske slovo, Chervonyi prapor), the author concludes, that the publications of the Organization of Ukrainian Nationalists consistently propagated sacred vocabulary in the articles, even on non-religious subjects (often to reproduce the elation and

(c) Ковтун А., Волинський національний університет імені Лесі Українки, 2021.

Це стаття відкритого доступу на умовах СC BY-NC 4.0 
triumph of what was being said). Textual syntagmatics of biblical-phraseological level unfolded both in familiar biblical situations (often through the introduction of colloquial elements in publicist speech, such as exclamatory units with religious components), and metaphors which retained the sacral dimension of the original semantics. A specific feature of the functioning of the religious lexicon in this newspaper material was the departure of religious lexemes beyond the traditional usage in the process of shaping ironic-satirical periphrastic units with their participation (червоний / большевицький / інтернаціональний paй - the red/ Bolshevik/international paradise; червоне царство сатани - the red kingdom of Satan; Сталінове "царство" / царство темряви, гніту і голоду - the Stalin "kingdom" / the kingdom of darkness, oppression and hunger).

The editorial policy of Krasnoye Znamya, the Soviet-era press organ, was aimed at avoiding religious themes, apparently without any political-ideological guidelines for this in the years 1939-1945. Only in the spring issue of 1945, this newspaper published a totally biased and lengthy article "With a cross or with a knife?" by V. Rossovych (Iaroslav Halan), targeting the Vatican, the Greek Catholic Church and Andrei Sheptytskyi.

Sensitive metaphors and metonymies, epithets and hyperboles, phraseology and neologisms, which included religious vocabulary (релігійний лубок - religious bast, боги свастики і тризуба - gods of swastika and trident, ультракатолицька шляхта - ultraCatholic szlachta, etc.), the extraction of words reserved for the religious sphere with the "weathering" of their semantics (вірник - believer $\rightarrow$ neologism довірник), biblical allusions, religious words in inverted commas as markers of irony were deployed to fulfill an order of defamation of Andrei Sheptytskyi and Catholicism altogether.

Key words: semantics, phraseology, biblical expression, biblical aphorism, biblical allusion, artistic means.

Вступ. Історія України радянського періоду пов'язана з порушенням прав українців на свободу віросповідання. До таких порушень належить рішення радянської влади, прибулої на західну Україну 1939 року, про ліквідацію Української греко-католицької церкви та утвердження російського православ'я з метою закріплення негайного впливу на місцевих жителів і 3 потреби «викорчовувати „ворогів народу”» (Дзюба 121). Реалізацію цього амбітного плану розпочали із зобов'язань католицьких священників мати спеціальні паспорти, платити податки за користування церквами і т. ін., а завершили 1946 року знищенням Української греко-католицької церкви на новоприєднаних західних землях УРСР.

Одним із засобів реалізації цього плану було негайне взяття під контроль засобів масової інформації, що сприяло запущенню могутньої ідеолого-пропагандистської машини, скерованої поширювати потрібні провладні міфи. Від вересня 1939 року, тобто від часу переходу радянських військ польсько-радянського кордону під приводом звільнення Галичини від польської окупації, до 22 червня 1941 року, або до активних воєнних дії німецьких загарбників, на західній Україні виходили друком кілька радянських газет. 3 початком війни, коли радянська влада залишила територію західної України, бо «радянський солдат не мав великого бажання воювати і захищати режим терору, якого боявся», а «більшість населення національних республік сподівалася, що конфлікт, який розпочався, принесе їм національну свободу» (Косик 103-4), до 1944 рр. 
з'явилася можливість активно працювати друкованим органам українських націоналістів, які відображали надскладне життя західних українців в умовах Другої світової війни. Випуск видань Організації українських націоналістів (ОУН) був зупинений 3 другим приходом радянської влади 1944 року. Натомість поновилося фальшиве тоталітарне слова - засіб поневолення свідомості людини, спотворення її мислення.

3 проголошенням незалежності українські історики активно відновлюють правдиві події 1939-1945 рр., пов'язані з маніпулятивними діями радянської влади, спрямованими на зміну релігійного вибору українців західної території України. Сучасні вітчизняні мовознавці досліджують функціонування релігійної лексики радянського періоду (В. Німчук, М. В. Скаб, П. Мацьків, Н. Піддубна, А.Ковтун, І. Ренчка, О. Ковтунець та ін.). Однак вивчення особливостей функціонування релігійної лексики на матеріалі західноукраїнського газетного мовлення радянського часу досі не було об’єктом мовознавчого дослідження, що становить актуальність цієї статті.

Мета дослідження - з'ясувати відмітні особливості функціонування релігійної лексики і фразеології у друкованих засобах масової інформації українських націоналістів та радянської влади на західній Україні в період Другої світової війни.

Матеріал і методи дослідження. Джерельною базою послугували такі газети воєнного періоду Львівської та Івано-Франківської (колишньої Станіславської) областей:

1. Низка друкованих органів українських націоналістів 1941-1944 рр.: «Останні вісті» (OB ${ }^{1}$ ) та «Воля Покуття» (ВП) - газети Коломиї, «Вільне Слово» (ВС) - Дрогобич, «Голос Підкарпаття» (ГП) Дрогобиччина, Самбірщина i Стрийщина, «Українські вісті» (УВ) м. Сокаль, «Рогатинське слово» (РС) - м. Рогатин, «Самостійна Україна» (СУ) та «Станіславське слово» (СС) - Станіславщина. Доступ для ознайомлення 3 ними нині надано читачам через відкритий архів української онлайн-періодики LABRARIA.

2. «Червоний прапор» (ЧП) - газета міста Коломиї, що функціонувала з 1 жовтня 1939 року, зі вступу радянських військ на територію Станіславського воєводства тодішньої Польщі, для роз'яснення причин входження Червоної Армії на Галичину та підготовки громадської думки про важливість узаконення акту злуки Західної України з Радянської Україною та Радянським Союзом. 1941 року газета «Червоний прапор» стала органом Коломийського міськкому і райкому КП(б)У, міської i районної Рад депутатів трудящих, що була під цензурою. 3 початком активних воєнних дії німецьких загарбників означений друкований засіб масової інформації призупинив свою діяльність, відновившись 1944 року з

${ }^{1}$ Тут і далі подаватимемо умовні позначення найменування газет. 
поверненням на Галичину. Один із примірників цієї газети збережений у Коломийському районному архіві.

Реалізацію цього дослідження здійснено за допомогою описового методу, що сприяв планомірній інвентаризації релігійних одиниць, залучених до західноукраїнського газетного мовлення періоду Другої світової війни, та поясненню особливостей їх функціонування (з використанням прийомів зіставлення, реконструкції та узагальнення); для відновлення розвитку оцінки понять, виражених релігійними лексемами, застосовано методику зовнішньої реконструкції порівняльно-історичного методу, для інтерпретації семантико-стилістичних параметрів релігійних лексем - функційний метод; релевантність значень релігійних лексем уточнено шляхом контекстного аналізу.

Результати дослідження та дискусія. Як відомо, газетне мовлення $\epsilon$ джерелом інформування суспільства, віддзеркаленням суспільнополітичної ідеології та формуванням громадської думки. Т. Коць зауважує: «В усі історичні періоди експліцитні психологічні оцінки переважали над абсолютними оцінками, що $є$ однією з визначальних диференційних ознак публіцистичного стилю як засобу формування масової свідомості» (Коць, «Оцінність» 84). Тематика преси друкованих органів українських націоналістів та радянської влади періоду Другої світової війни мають разючі відмінності. Проаналізуємо їх.

У виданнях ОУН 1941-1944 pp. релігійні теми висвітлювали регулярно. Подаємо мініконтексти з релігійними лексеми як маркерами омовлення релігійної сфери, які пізніше, за радянської влади, були обмежені в ужитку через ідеологічний курс держави: I ось наближається та Свята Ніч, надихана запахом соснового віття й овіяна таємничим сяйвом свіч, коли люди пригадують собі, що є в людях, бажаючи собі: Слава во вишніх Богу і на землі мир людям благовоління (СС, 1942, № 11); Вірою побачимо воскресшого Христа і на крилах небесної надії і більше ніж небесної, бо Божої любови, піднесемося на небо до Христа, Спасителя, до Пречистої Діви, піднесемося до неба, до мети цілого життя (ВП, 1943, № 4); 3 них довідуємося, що цей великий патріот і мещенат прибув до Коломиї з міста Сучави на Буковині, де як священник-целебат займав посаду гр. кат. катехита (ВП, 1944, № 15); Я священник, а тому хочу Вас перед смертю зєднати з Богом. Хто має на своїй совісті якісь гріхи, не хай тепер заглибиться в собі, не хай щиро покається. Всевишній Господь, що бачить Ваші страждання, все Вам простить (ВС, 1941, № 7); 3 Ватиканських кругів розійшлась вістка, що Сталін, який досі був найлютішим ворогом христіянства, намагається навязати звязки з Апостольською Столищею. Починається пекло. Наш друг Бучинський порадив хлопцям одягнутися без шуму й гамору (ВП, 1941, № 4) та багато ін.

\footnotetext{
${ }^{1}$ Тут і далі після умовного позначення найменування газети подаватимемо рік і номер видання.
} 
Релігійну лексику систематично залучали до оповідей на різні болючі теми, пов'язані із загарбниками (німецькими та радянськими), 3 долею рідної землі, її вірними синами й дочками та ін.: Та Божсе Провидіння не допустило до того. Адольф Гітлєр скинув з народу соромне ярмо версайських переможців та, викресавши при допомозі націоналсоціялістичного руху дрімучі сили народу, довів Німеччину до небувалої досі величі й могучости (УС, 1944, № 15); Большевицька влада й ціла їх безбожсницька акція не зуміли вирвати українському народові віри в Бога (УС, 1943, № 51); Сам Бог витає над селом. Та де поділась та краса українського села? (ВС, 1941, № 16); Інші складники його расової московської приналежносте не позволяли на це, такі як бездушний послух, брак спротиву злу, почуття всеросійської великодержавної солідарносте (УС, 1042, № 7); Здавалося, твоїм стражданням кінця не буде. I так, віками поневолена, шматована, з скривавленим тілом і навхрест рознятими руками, з очима, залитими слізьми, і виснаженими вустами, з тяжким болем у серці і щирими молитвами до Бога Ти йшла. Йшла терновими шляхами, пригортаючи до лона Материнською любовю своїх знедолених дітей.. (ВС, 1941, № 6); I молю Бога, щоб Украӥнська держава, сперта на Божсому законі, забезпечила щастя, добробут і спокійне життя всім громадянам української землі без огляду на різниці віроісповідні, національні і суспільні (ВП, 1941, № 4); Великий Каменяр і будівничий нового українського суспільства <..> трудився серед невідрадних умовин особистого та громадського життя поверх сорок літ, як той біблійний Мойсей (ВП, 1942, № 33) та багато ін.

У виданнях українських націоналістів активно функціонували назви релігійних осіб (Бог, Господь, Всевишній, Всемилостивий, Отещь, Спаситель, Ісус Христос, Син Божий, Христос-Богодитя, Мойсей, Матір Божа, Пресвята Богородиця, дух, душа, ангел, апостол, священник, отець, всечесний, отець, панотець, парох, душпастир, християнин, прочанин, праведник, мученик, грішник та ін.), споруд, їхніх частин та предметів (церква, храм, каплиця, вівтар, хрест, образ та ін.), процесів, дій, опредметнених дій та свят (молитися, освячувати, благословити, богослужіння, освячення, панахида, молитва, віра, Різдво, Великдень та ін.), ознак, пов'язаних 3 релігією (благословенний, святий, священний, побожний, многострадальний, небесний та ін.). Кожна п'ята актуалізація - у переносному значенні: Дух Міхновського, Петлюри, Коновальця вказує нам путь і провадить нас до остаточної перемоги (ВП, 1942, № 44); Ідея фізичного виховання - це не особистий тілесний інтерес одиниці, це інтерес духа нації, інтерес фізичної тугости і справносте усіх шарів українського народу (ВП, 1942, № 17); Тривогу, тугу, надію і любов усе те заклав наш нарід у пісню, найкращу повірнищю-розрадницю своєї душі (ВП, 1943, № 24); Забуття всіх життєвих злиднів, злет понад сіру буденщину, якийсь дивний спокій з глибокою за думою та пречистою погодою душі (ВП, 1943, № 2); 
...ніжна та артистична душа поета (ВП, 1943, № 3); Церква ніколи не перестає повторювати науку Божих заповідей, перестерігати перед злочинами, пригадувати Божу кару та вказувати народам дорогу вірного сповнення Божої волі, як одиноку дорогу до осягнення кращої будучности (ВП, 1943, № 33) та ін.

Потребу створення особливого урочисто-піднесеного колориту мовлення досить часто реалізовували саме завдяки введенню до контекстів сакральної лексики - неторканих мовних знаків з релігійних дискурсів, часто символьних, що інкорпорують великий обсяг знань, відомих для християнського світу, здебільшого 3 позитивними емоційними та оцінними конотаціями: Вірю в Месію України, що вбавиться творчим поривом Духа, зусиллями волі, запалом любови... (СУ, 1941, № 1); Бог послав Україні Месію - Шевченка, апостола українського національного світогляду (Г, 2017, № 48); На вівтар покладено чимало людських душ, а до нього через роки і віки тягнуться довгі ряди спасителів, мучеників, апостолів (ГП, 2014, № 50); Кожний з нас мусить зайняти своє місце в тих рядах, де його поставить життя і мусить виконати обов'язок так, як показує наш Вождь, наш Мойсей (І. Франко. - А. К.), що веде нас світлий храм української державности (ГП, 1941, № 7); Розбудуйте в душах Божий храм, щоб не повторити великий гріх (ВП, 1943, № 15); Коли людина відчуває в собі силу створити храм, особливо не грішить та молиться (УВ, 1941, № 23). У храм природи ідіть із чистим серщем (СС, 1944, № 2); Недарма Ви дали в офірі кров свою - воскресне Вітчизна! (ВП, 1942, № 32); Тоді лише стануть у правдивій величі перед воскресшою нацією їі два великі сини Симон Петлюра та Євген Коновалещь (ВП, 1942, № 32).

Широке функційне поле бібліїзмів - слів, виражених словами й висловами «зі Святого Письма (Біблії), що ввійшли в загальну мову» (Жайворонок 48) - засвідчує виконання у пресі ОУН 1941-1944 pp. притаманних епіфункцій: пізнавальної (транслювання мовним знаком правди чи неправди про об'єкт мовлення), експресивної (створення почуттєво-оцінної напруги) та імпресивної (вплив мовного знака на адресата повідомлення) функцій бібліїзмів, базованих «на низці взаємодоповнювальних та взаємоувиразнювальних інформативних, прагматичних, контактновстановлювальних, кооперативних» (Галаур 74). Помітною $\epsilon$ експлікація загальновідомих біблійних ситуацій: ...бути кожної хвилини готовим умирати і ставати перед Божий суд, бути усе готовим приступати до св. Причастія (ВП, 1941, № 7), Божий суд над жидівським нацьковувачем до війни (ВС, 1941, № 14); Хліб - це дар Божий! Хто продає своє зерно, грішить супроти Бога, держави і народу та підлягає суворій карі (РС, 1941, № 3). Текстове вплітання біблійних цитат «розширює контекст сприйняття <...>, поєднуючи інформаційні поля різних дискурсів, підкреслюючи їхні спільні ідеї, теми, мотиви, сюжети» (Коч 213): Стукайте, а вам отвориться! Залунав дзвін з церковної вежі і сповістив громадянам про велике свято. Велике, бо громадяни с. Юнашкова 
такого не пам'ятають. Хто живий, до церкви прямує як у «Перший Великдень на волі» (ВП, 1943, № 13) $\leftarrow$ Простіть, а дасться вам, шукайте, а знайдете, стукайте, а отворять вам (Мт. 7: 7).

У досліджуваних текстах, однак, виявлено ширше функціонування фразеологізмів біблійного походження 3 похідною семантикою, що зазнали метафорного переосмислення, слугуючи вихідною базою для позначення узагальнених, абстрактних понять. Такі використання «містять компонент оцінки, виражають позитивні чи негативні почуття, характеризують психічний стан мовця, передбачаючи існування додаткового стилістичного колориту» (Вергалюк 38): Народ терпів і йшов далі тернистим шляхом, складаючи нові й нові жертви (ВС, 1941, № 15); Мойсей (І.Франко. - А.К.) умер, не діждавшися входу свого народу в Обітовану Землю... (РС, 1941, № 11); В прах розбиває темні сили та лютих ірвідів, що в зародку хочуть вбити, знищити новонароджену ідею, замкнути вхід змученому людству у нову землю обітовану (ВП, 1942, № 1). Багато таких семантично оновлених бібліїзмів мають стрижневе слово - дієслово; Для людей, у яких віра - в Бога не є засобом на живи, які справді вірять в Бога і знають, що ия віра стоїть у повній згоді зі справжньою наукою, стало пекучою потребою душі і моральним обов'язком допомагати іншим українцям віднайти втрачені шляхи до Бога наших батьків (ВС, 1942, № 15); Ставайте до праці на народній ниві, не чекайте на манну з неба (ВП, 1942, № 8); Героїчний подвиг украӥнський народ їм ніколи не забуде тоді, коли із мертвих повстане, як і не забуде їм Христос, коли воскресить їх до вічного життя (ВП, 1944, № 35); Такі роботи в святі дні будуть для і багатьох з вас прикрим і тяжким хрестам (ВП, 1942, № 12).

Вітчизняні дослідники зауважують, що в українськомовних ЗМІ XXI ст., почастішало «живе» (спонтанне, розкуте) мовлення, яке приваблює виявленням лінгвокреативності «мовних особистостей, сприяє омовленню почуттів, емоцій, що особливо характерно для представників української нації, в мовленні яких, як відомо, вербалізується філософія кордоценризму, лінгвостилістична категорія інтимізації, словотворчість для омовлення гумору і под.» (Космеда 45). Можемо стверджувати, що розвиток інформаційного мовлення галичан періоду Другої світової війни, яка ще не знала «совка», також відбувався демократичним шляхом. За матеріалами аналізованих видань українських націоналістів, автори публікацій досить активно використовували, наприклад, вигукові фразеологізми 3 релігійним компонентом, характерні для розмовного стилю. Майже для кожного газетного номера таке явище було звичним, віддзеркалювало глибоку традицію щоденного використання релігійних сталих висловів у мовленні галичан, зокрема з лексемою Бог, коли вони: 1) дякували Богові: Дякую Всевишньому з глибини душі за вислухання наших благальних молитов (ВП, 1941, № 4); Переможия до Києва, до Святої Софії, щоб тут в старинній святині зложити Всевишньому подяку за перемогу $i$ освободження (СУ, 1941, № 1); Щоби Всевишньому подякувати за все, що 
дав і упросити потрібних ласк на майбутне (ВС, 1941, № 2); За ще Воскресения Український Нарід із сльозами радости на очах складає в молитвах глибоку подяку Господу Богу і Покровительці нашого народу Матері Божій, бо це ж вони послали нам спасения... (ВС, 1941, № 2); 2) вимолювали що-небудь у Бога для себе чи кого-небудь: Зривається $i$ знову біжить дальше... Боже, дай добігти в час!.. (ВП, 1943, № 17); I молю Бога, щоб Українська держава, сперта на Божому законі, забезпечила щастя, добробут і спокійне життя всім громадянам украӥнської землі без огляду на різниці віроісповідні, національні і суспільні (ВП, 1941, № 5); Якщо ні, то до таборів примусової праці, а там не дай Боже як живуть (УС, 1941, № 22); 3) просили в Бога благословення: Сильним молотом ударяли ритмічно дитячі серия, що невпинно благали: «Боже, пошли Україні крашу долю, благослови наші діла» (ВП, 1941, № 11); Нехай Всевишній Бог благословить Вас усіх, до яких те моє слово дійде, i всіх, до яких не дійде (ВC, 1942, № 5); Бог нехай благословить усі праці народу та дасть усім провідникам Української Держави святу мудрість (ВП, 1941, № 3); 4) присягалися перед Богом у відданості: Непереможні є сили українського народу, незломна його поля бути господарем своєї землі, незаглушимі у нас бажання жити життям вільних людей, служити своїй правді, свойому Богу покланятися (ВС, 1941, № 1); В своїй промові він згадав про тяжкі терпіння нашого народу за часів большевиџької неволі, коли то було заборонено не тільки вірувати в Бога, ходити до церкви, але й жити по свойому по-українськи (ВП, 1942, № 2) та ін.

Прикметною особливістю преси українських націоналістів періоду війни $з$ німецькими загарбниками було творення іронійних і навіть саркастичних перифраз, до складу яких входила релігійна лексика. Мета таких описових мовних зворотів - відобразити ставлення до Сталіна та його соратників. Для цього широко використовували лексему рай в енантіосемійному значенні «нестерпні, жахливі умови, обставини», рідше пекло, додавали означення:

- червоний «який стосується революційної діяльності; пов'язаний 3 радянським соціалістичним ладом» (Словник української 11: 441): У нас дбала вона за правильну організацію роботи, за хід лекцій марксизмуленінізму, за проведення большевицької агітки за «червоний рай» (BC, 1941, № 17); Переживши 20 років лютих переслідувань та катувань в «щасливому червоному раю» (СУ, 1941, № 2); Украӥнська мова всюди свобідно лунала й на хвилях повітря йшла й до Вас, страдаючі браття й сестри в червоному пеклі (ВС, 1941, № 2);

- большевицький «власт. більшовикам» (Словник украӥнської 1: 187): Але радіючи волею, мимоволі серце стискається від болю, коли згадуєш «большевицький рай»... (ВС, 1941, № 4); Але радіючи волею, мимоволі серце стискається від болю, коли згадуєш «большевищький рай», "радісне й заможне життя» на східніх землях України (ВП, 1941, № 4); Коли гляджу в обличчя жінки українки, що їй варвар зо Сходу забрав і жорстоко 
закатував усіх найближчих, згадую чудову новелю Хвильового «Мати» й думаю, що Хвильовий все ж таки не пережив ще всього до дна большевицького пекла (ВС, 1941, № 23);

- інтернаціональний «стос. до різних народів, націй; міжнародний» (Словник української 4: 39): На терорі побудували інтернаціональний «рай», нову комуністичну тюрму народів (BC,1941, № 2).

Саркастично звучать перифрази з лексемою царство (у Новому Завіті про Царство Боже згадано більш ніж 100 разів): А ось, на мою думку, то варто було б вислати ще й полки сліпих. Цих бідолах в царстві Сталіна не бракує (ВС, 1941, № 20); Англійський письменник Мелькольм відвідав на запрошення совєтського правительства, Сталінове «царство» (ОВ, 1941, № 14); Німецька Армія попередила напад і почала свій переможний наступ на царство Сталіна, царство темряви, гніту і голоду (ВС, 1941, № 8); Всі до боротьби з червоним царством сатани, з царством мук, насилля, брехні (РС, 1941, № 5).

Аналіз випусків 1939-1941 рр. коломийського друкованого органу радянської влади «Червоний прапор» засвідчує висвітлення подій, які відбувалися в СРСР, та міжнародної інформації. Головною ідеєю цього друкованого засобу масової інформації була масштабна пропаганда доцільності радянської системи й підтримання внутрішньої позики держави. Важливо було переконати галичан, що визріли нові реалії життя та суспільно-економічні виклики, тому потрібно підкорятися новій системі господарювання й торгівлі, мирилися з обмеженнями задля організації колгоспів, прагнути перевиконання виробничих планів та ін. Редакція газети також приділяла багато уваги описові вступу Червоної Армії до Бессарабії та Північної Буковини, що, як стверджувалося, «рятувала від румунського рабства» галицьких сусідів, а насправді повторювала «галицько-визвольний» сценарій (Васильчук 115). Популяризували нові радянські свята, регулярно тавруючи в багатьох памфлетах український буржуазний націоналізм, що міг завадити досягненню перспективи злуки Західної України з СРСР. Газета «Червоний прапор» цілком відповідала усім вимогам друкованих засобів масової інформації в тоталітарній державі, що були «наскрізь офіціозними й стовідсотково контрольованими» (Капітан 44). За нашими спостереженнями, коломийська районна газета висвітлювала місцеві події мало. У такий спосіб влада намагалася «приспати» історію західноукраїнського краю. Після повторної окупації 1944 року Галичини відроджений «Червоний прапор» уже відкрито засуджував патріотичний український рух на окупованих західноукраїнських територіях, називаючи оунівців зрадниками українського народу.

Огляд матеріалів коломийської газети «Червоний прапор» 1939-1945 рр. продемонстрував, що ії редакція, незважаючи на набожність місцевого населення, уникала релігійних тем щодо ставлення до релігійних уподобань місцевих. Відомо, що на інших, українських територіях, більшовики вели атеїстичну пропаганду, проповідуючи 
безбожжя як характерну рису збірного образу громадянина СРСР. Як зауважує Т. Коць, «у 40-50-х роках XX ст. основним мовним ресурсом публіцистичного стилю були виразні експресиви, які вибудовували нову шкалу цінностей - партії, радянського народу, позитивна конотація яких виразно контрастувала з експліцитними негативно оцінними поняттями релігією, націоналізмом, фашизмом, війною. Утвердження радянської ідеології відбувалося шляхом заперечення традиційних позитивно оцінних понять - духовності, національної ідеї, християнських ідеалів» (Коць, Публіцистичний 5).

Припускаємо, що до 1945 року журналісти «Червоного прапора»не мали конкретних політико-ідеологічних настанов торкатися релігійних тем, тому майже не використовували релігійної лексики і фразеології. Однак у випуску № 41-42 за 18 квітня 1945 року поновленої після другої радянської окупації газети було надруковано велику (майже на три сторінки) відверто замовну статтю під назвою «3 хрестом чи 3 ножем?», автором якої був Володимир Росович (справжнє ім'я - Ярослав Галан, який написав низку антиватіканських памфлетів: «Що таке унія», «Отець тьми і присні», «На службі в сатани», «Апостол зради», «Годі!», «Плюю на папу»). Санкціонований владою антиуніатський памфлет був спрямований проти Ватикану i Греко-католицької церкви, яка нібито здійснювала у вітчизняній історії дещо «специфічну», але вочевидь негативну місію. В. Росович у своєму пасквілі порушив питання шкоди від Української уніатської церкви на чолі з Андреєм Шептицьким - предстоятелем Української греко-католицької церкви, якого раніше, до його смерті (помер за пів року до виходу статті, 1 листопада 1944 року), чіпати боялися, беручи до уваги авторитет цього відомого українського релігійного і громадського діяча.

Замовність статті не викликає сумнівів, оскільки у коломийську районну газету її було передруковано з львівської обласної газети «Вільна Україна» (там Я. Галан працював кореспондентом у 1939-1941рр.) за тиждень (у кінці статті читаємо: «Вільна Україна» 8 квітня 1945 р.). Інші західноукраїнські часописи цю статтю опублікували також, а невдовзі вона з'явилася і у вигляді окремої брошури, надрукованої у Львові двома виданнями 1945 й 1947 р. загальним накладом 151 тис. примірників. Влада на той час уже запланувала підготовчі дії для «возз'єднання» УГКЦ та РПЦ, вирішивши розпочати зі звинувачення покійного митрополита Андрея Шептицького, його наступника Йосипа Сліпого та арешту грекокатолицького єпископату у співпраці з німецькими окупантами, у зв'язках з ОУН. Було здійснено спробу змінити громадську думку для проведення подальших репресивних заходів проти ієрархів УГКЦ.

Мотивом для появи статі «3 хрестом чи 3 ножем?» послугувало Пастирське послання Андрея Шептицького, видане 1 липня 1941 року в знак підтримки проголошеної Я.Стецьком незалежності Української держави, у якому німців потрактовано як визволителів. Звісно, ніхто не 
зважив на пізніші протестні звернення А. Шептицького до райхсфюрера СС Гімлера, на лист до Папи, у яких ішлося про антилюдські вчинки німецької влади, на визнання їі монстром, потворою, диявольською силою тощо. Більшовицька влада вирішила заплямувати імя головного представника Української греко-католицької церкви А. Шептицького, який під час установлення незалежної Західно-Української Народної Республіки 1917 року, зокрема, сказав таке: «Якою б не була Росія, вона добровільно не зречеться своєї влади над Україною. Але якщо Україна хоче жити вільним життям, то мусить обов'язково відокремитися від Москви, повинна стати незалежною державою, шукати собі союзників серед інших вільних народів» та ін.

Зупинимося детальніше на цій статті, щоб зрозуміти різницю у використанні лексичних і фразеологічних засобів у висвітлення релігійних тем, актуальних для західноукраїнського читача періоду Другої світової війни, друкованими засобами масової інформації радянської влади та українськими націоналістами.

Автор статті «3 хрестом чи 3 ножем?» лише дин раз називає головного героя своєї оповіді Андрієм Шептицьким (з іменем), на початку статті, одразу наголосивши, що він українізований поляк (не українець) і граф, з поміщицького роду. В. Росович усвідомлював, що читач уже «підготовлений» політикою ліквідації куркулів як класу на базі суспільної колективізації 30-х рр. й насторожено ставиться до графського походження будь-кого. Далі, виконуючи соціальне замовлення «словесного огиджування» образу А. Шептицького (таке формулювання вводить Л. Масенко (69) для характеристики образу куркуля), автор користується лише прізвищем Шептицький (без імені), що $є$ конотативно забарвленою формою називання, і майже не залучає нейтральних форм називання. Як саме автор передає замовну огуду до митрополита Андрея Шептицького? Відкрито й демонстративно. Від першого до останнього рядка статті читача супроводжують два авторські посилання: 1) багатство для А. Шептицького $\epsilon$ кредом його житті: усе, що він робив, - заради багатства; саме воно й сприяло розвиткові його «головокружної» кар'єри; 2) графське честолюбство мало величезні масштаби і не зважало на ціну. Кілька разів В. Росович повторює, співаючи своєї, що А. Шептицький - один із представників святоюрської гори (гора - символ влади, божественності). Іронізуючи, перейменовує її на Сінайську, з якої митрополит нібито, якщо й сходить на землю, то не для того, щоб втихомирювати пристрасті й мирити розсварених, бо має голубу кров (метафора стосується «аристократів»: Як і личить дипломатові голубої крові...). Іще одна схожа метафора, повязана з графським потягом А. Шептицького до розкоші, мури його палацу: Шептицький пильно, сторожко слідить за всім, що діється за мурами його палацу. 
Зосередившись на багатстві А. Шептицького, автор намагається розвінчати «нещиру» релігійність митрополита, якого вважають великим філантропом (Маючи в своєму розпорядженні величезний маєток та субсидії з різних джерел, він широко розгортає філантропічну діяльність). В. Росович переконує читача в крутійстві графа, що «мудрує» задля власного зиску. У статті згадано, зокрема, спробу відомого католицького духівника обхитрити вірних за допомогою пригальмування латинізаційного запалу ініціаторів окатоличення задля здобуття слави охоронця грецького обряду і «великого страдальця за народ», безкорисливого й щедрого мецената для вірян тощо. Здебільшого автор робить це метафорно (Земне добро стає в його руках золотим ланцюгом, щеㅇ приковує паству до митрополичого престолу) і вї̈дливо (...цей релігійний лубок, підсолоджений сльозливим культом Марії, мав перш за все на меті віддалити галицьких українців від їх наддніпрянських братів, будь-що ізолювати їх від революційних ідей <...>). Дошкульною метафорою релігійний лубок, що в останньому прикладі, окреслено вкрай негативне ставлення до затятого уніатського духівника, який нібито ширить старомодні неоковирні погляди і з яким ніяк не можна домовитися. Використаний полісемант лубок, як і фразеологізми з луб чи словотвірні похідні лексеми від луб, - усі містять негативні конотати: луби «задники» (Шкрумеляк 89), лубочний «невисокої якості, примітивний виконанням, розрахований на невибагливий смак» (Словник української 4: 551), луб'яний «негнучкий, невправний» (Словник української 4: 551), лубкий «крав. грубий, твердий» (Шкрумеляк 89), лубом стояти (стати) «бути твердим, цупким» (Словник української 4: 551), старе луб'я «фам., зневажл. про стару людину» (Словник української 4: 551) / «жарт., неважл людина похилого віку» (Фразеологічний 355), як (мов, ніби і т. ін.) з луба «зі словом лити, дуже сильно (про дощ)» (Фразеологічний 355) та ін. Недолугість папського легата автор замовної статті вбачає в неспроможності збагнути ціну своєї скнарості з бажання утримати свою кар'єру.

Метафора цей релігійний лубок, підсолоджений сльозливим культом Mapiї дуже нагадує одну із цитат вождя світового пролетаріату Леніна, який у своїх «Філософських зошитах» зауважив про напис на хресті «Зжалься, милосердний Ісусе! Святая Маріє, молися за нас!» так: Тут перед нами безмірне смирення християнства в усій його жалюгідній нікчемності. Бо той, то покладає таким чином усі свої надії на жалість, той воістину жалюгідне створіння, а про гегелівське тлумачення християнства коментує: Вульгарно-попівське ідеологічне базікання про велич христиняства (з цитатами з Євангелія!!). Мерзенно, смердюче! (цит. за Бенкендорф 16). Коли В. Росович називає Російську Православну Церкву оказіональною перифразою оксюморонного типу православні «єретики» $\mathrm{i}$ згадує при цьому Росію (Все це було надихане ненавистю до православних 
«єретиків» $i$ до Росіі), виникає питання, чи справді навернення до православ'я полонених хрестоносців з «єгипетської неволі» було щирим.

Автор вказує на всегребущі руки невблаганних католицьких гнобителів, руки позбавленої корита польської шляхти, чия кипуча енергія $i$ честолюбство не дозволяють приглядатися до розвитку подій iз заложеними руками. Фразеологізмами всегребущі руки $\leftarrow$ загрубущі руки «хто-небудь дуже жадібний, ненаситний, прагне до наживи» (Фразеологічний 623), приглядатися із заложеними руками $(\leftarrow$ сидіти зі складеними (зложеними, заложеними) руками «ледарювати, нічого не робити» (Словник фразеологізмів 198) наголошено на зажерливості церковних служителів уніантської церкви. В. Росович, окреслюючи життєвий шлях А. Шептицького (новоспечений «вірний», згодом - найвищий церковний «достойник» святоюрського середовища, наприкінці - немічний nacmup, який до останнього подиху намагався впливати на політику), прагне змалювати, за його формулюванням, деморалізовану уніатську церкву, представниками якої є люди, що називають себе священниками, духівниками, церковними служителями, прелатами, єпископами, кардиналами, владиками та ін. «Витягує» зарезервоване для релігійної сфери слово вірник, «вивітрюючи» його через творений спільнокореневий неологізм довірник: Багато з викоханих ним його вірників $і$ довірників щораз більш ворожим оком дивились на свого немічного пастиря. Між рядків «пробивається» до читача фразеологізм влазить (вкрадається, втирається і т. ін.) в довір'я. До всього, автор посилює відкриття сакрального резервувару поєднанням слова пастир зі словом немічний.

Для розвінчування заслуг того, хто був прикладом для наслідування мільйонів українців, у статті використано біблійну афористику. Біблію, як відомо, «справедливо вважають одним із найчастотніших (і найвагоміших) інтекстових компонентів, частина яких має статус прецедентності за умов реалізації певного їі фрагмента як мовного афоризму» (Богдан 15). За допомогою влучності біблійних крилатих висловів, що ввійшли до фразеологічного фонду української мови як невід'ємні складники їі системи, автор створює прямо протилежну, негативну, характеристику митрополита, заповітами якого було вчення віри та любові до ближнього, свідомого християнства й національного патріотизму. Назва статті «3 хрестом чи 3 мечем?» $€$ біблійною алюзією - популярною формою публіцистичної інтертекстуальності, що містить натяки на тексти Святого Писання 3 актуалізацією різних біблійних сюжетів, розрахованих «на знання і проникливість читача, що має запропонований натяк сприйняти і відповідним чином витлумачити» (Колоїз 4). Ця риторична назва вибудована на відомому євангельському сюжеті, який вчить не ініціювати воєн: Тоді каже йому Ісус: сховай свого меча в його місце, бо всі, хто візьме меча, від меча загинуть (Мт. 26: 52). Заголовок «3 хрестом чи з мечем?» закликає читачів глянути на свого духовного лідера як на маніпулятора свідомістю вірян, оскільки дії та вчинки його як пастиря нібито не 
відповідають євангельським заповітам, які він проповідує. Автор статті наголошує на цьому й тоді, наприклад, коли з багатьох назв ознаки належності до духовного сану обирає саме лексему пастирські й разом зі словом листи бере іï в лапки, щоб закріпити іронійність сказаного: $B$ одному з «пастирських листів» оголошеному в перші місяці фашистської інтервенції в Іспанії, Шептицький закликає йти слідами... Підзаголовки памфлету також інтертекстуальні, пов'язані з текстами Святого Писання: «В терновому вінку», «Чистилище», «Рай», «Пекло», «Голос у пустелі», «Камо глядеші?». Імпліцитність указаної біблійної алюзії в тексті статті часто декодована конкретною інформацією про побратимів по вірі А. Шептицького, що поглиблює негативну оцінку дій католицьких провідників: Були й такі, які вдень носили хрест на грудях, а вночі, озброєні пістолетами, пліч-о-пліч з оунівськими бандами вбивали радянських активістів.

В. Росович поступово, упродовж статті, веде читача до розуміння тісного зв'язку священнослужителів й націоналістів - агентів людожера Гітлера. Наголошує на войовничості католицизму, представники якого вдягнені в єпископські убори, в ряси уніатських священиків і носять хрести, а насправді, за його переконаннями, $є$ гітлерівськими помагачами, служниками богів свастики і тризуба. Через образ християнського символу автор занурює читача в інший символ - нацистський хрест, свастику, i одразу ж, поруч, зосереджує ще й третій - український тризуб (чудесний «тризуб»). За допомогою різних образних засобів (метонімій, метафор, епітетів, гіпербол, стилістичних фігур) багато разів повторює, що католицькі священники й українські націоналісти діяли злагоджено, шкодячи народові: Церковні амвони стають поступово трибуною українського воюючого націоналізму (метонімія й метафора); Кадри уніатського духівництва впродовж 15 років поповнились здебільшого шибайголовами з УГА і петлюрівцями та декласованими молодчиками, які почали раніше молитися Коновальцеві, ніж богові (гіпербола); Цей жест мав свідчити про те, що, мовляв, уніатське духівництво, як і всі українськонімецькі націоналісти, назавжди звязало свою долю з долею німецьких вбивць і грабіжників та В той час багато уніатських церков стають кузнями антирадянських провокацій, а чимало священиків - надійними охоронцями гітлерівських шпигунів і диверсантів (поєднання релігійної лексики 3 фразеологізмами метафорного походження); шляхта ультракатолицька, ультрарозбещена (авторські неологічні епітети) та ін.

Автор враховує фонові знання читачів про прецедентні релігійні тексти, без чого біблійна алюзія є неможливою. У статті спостережена апеляція до загальновідомого біблійного персонажа Мойсея - вождя єврейського народу, першого священного автора й одного 3 найважливіших пророків для юдеїв, християн і мусульман та вірних інших релігій. Мойсеєм названо А. Шептицького, але, зрозуміло, в іронійному контексті: Як і личить дипломатові голубої крові, він зберігав спокій, 
залюбки виступаючи в ролі Мойсея, який воліє розмовляти з богом, ніж з юрбою. Іронійність цього твердження - у розвінчуванні ідеального А. Шептицького, який буцімто пишається своєю винятковістю, любить славу і зневажає свій народ.

Автор публікації, зіставляючи митрополита з Мойсеєм, нагадує про нещасливий кінець життя А. Шептицького, схожий на Ісуса, якого увінчали перед смертю терновим вінком: Адже серед безлічі його вінків бракує ще одного: тернового. За Біблією, римські солдати поклали вінець з колючок на голову Ісуса Христа, а в руки - тростину як скіпетр, одягнули в багряницю - царські символи, насміхаючись над Ним, понівеченим, та плюючи на Нього (Мт. 27: 11, Мр. 15: 2, Лк. 23: 3). Діяння А. Шептицького, що пройшов тернистий шлях від монаха до митрополита, подано в статті через прийом глузування, орієнтований на переосмислення читачами заслуг їхнього пастиря, відмову від його ідеалізації. Про діяльність духівника сказано як про звичайну працю того, хто рухає вверх свою карєру в якійсь професійній сфері (Кар'єра головокружна. У 1891 році призначений священиком, він уже через 8 років стає єпіскопом, а рік пізніше - митрополитом).

За допомогою лапок автор робить спробу відкрити очі на правду православним, себто українцям: Його вони «висвятили» на першого уніатського владику. У памфлеті релігійні лексеми, як маркери об'єктів для іронізування, досить часто взяті в лапки: це «висвячення» скінчилося для новоспеченого «вірного»; ...націоналістична преса співає йому «осанна»; найвищий церковний «достойник»; легенда про його «мученищтво» росте як на дріжджах; уніатський «духівник», новоспечений «вірний» та ін. Лапки візуалізують авторську мету - перетворити пасивного споживача інформації на активного інтерпретатора, адже іронія спроможна узаконити відомий «розкол» між «ідеальним» (смисловим) і «матеріальним» (мовним) аспектами іронії, ревізіонувати зв'язок лінгвального та екстралінгвального компонентів у структурі концепту іронії (Веселова 2003).

Висновки та перспективи досліджень. У пресі ОУН 1941-1944 pp. Львівської та Івано-Франківської (колишньої Станіславської) областей регулярно ширили сакральну лексику у статтях навіть нерелігійної тематики, часто щоб відтворити піднесений настрій чи надати сказаному урочистості. Текстова синтагматика біблійно-фразеологічного рівня розгортається як звичними біблійними ситуаціями, так і метафорами, що зберігають сакральний вимір вихідної семантики, нерідко й через орозмовлення публіцистичного мовлення вигуковими одиницями 3 релігійними компонетами. Єдиною специфічною рисою виходу релігійних лексем за межі традиційного $\epsilon$ формування 3 їх участю іронійносатиричних перифразних одиниць, які вказують на непримиренність галичан до радянських принципів життя. 
Редакційна політика друкованого органу радянської влади «Червоний прапор» 1939-1945 рр. була спрямована на уникнення релігійних тем. Але у весняному номері 1945 року цієї газети було надруковано розлогу відверто замовну статтю «3 хрестом чи з ножем?» В. Росовича (Я. Галана), спрямовану проти А. Шептицького. За допомогою дошкульних метафор й метонімій, епітетів й гіпербол, фразеологізмів й неологізмамів, до складу яких увійшла релігійна лексика, через витягування зарезервованих для релігійної сфери слів з «вивітренням» їхньої семантики, побудову біблійних алюзій, взаємодію вербальних та візуальних (лапок) елементів письма було виконано соціальне замовлення «словесного огиджування» образу А. Шептицького та всієї Української греко-католицької церкви.

Перспектива цього дослідження - з'ясування особливостей подальшого розвитку релігійної лексики в друкованих ЗМІ радянського періоду та незалежної України.

\section{Список використаних джерел}

LABRARIA: архів української періодики онлайн. URL: https://libraria.ua/all-titles/.

Червоний прапор: орган Коломийського міськкому і райкому КП(б)У міськради i райвиконкому Станіславської області. 1.10.1939-31.12.1945.

\section{Sources}

LABRARIA: arkhiv ukrainskoi periodyky onlain. libraria.ua/all-titles/.

Chervonyi prapor: orhan Kolomyiskoho miskkomu i raikomu KP(b)U miskrady i raivykonkomu Stanislavskoi oblasti. 1.10.1939-31.12.1945.

\section{Список використаної літератури}

Бенкендорф, Геннадій. «Христос і християнство. Семантика та прагматика концептів у мові тоталітарних партій». Наукові записки НаУКМА, т. 34, 2004, с. 15-21.

Богдан, Світлана. «Біблеїзми в системі епістолярного автопортретування Лесі Українки». Волинь філологічна: текст і контекст, вип. 17, 2014, с. 15-36.

Васильчук, Микола. Українська видавнича справа у Коломиї (друга половина XIX-XX ст.). Коломия, 2012.

Вергалюк, Марія. «Функції біблійних фразеологізмів у художніх текстах». Науковий вісник Чернівецького університету. Романо-слов'янський дискурс, вип. 812, 2019, c. $36-40$.

Веселова, Наталья. Ирония в политическом дискурсе. Дисс. ... канд. филол. наук: 10.02.04. Нижний Новгород, 2003.

Галаур, Світлана. «Бібліїзми-регулятеми в сучасній українській художній прозі». Науковий вісник Чернівецького університету. Романо-слов'янський дискурс, вип. 812, 2019, с. 73-7.

Дзюба, Іван. Тридиять років зі Сталіним. П’ятдесят років без Сталіна. Київ: Криниця, 2003.

Жайворонок, Віталій. «Біблеїзми». Українська мова: енциклопедія, за ред. В. М. Русанівського, і О. О. Тараненка. Київ, 2007, с. 48-9.

Капітан, Лариса. «Російська православна церква як знаряддя утвердження моноконфесійності Закарпаття (повоєнні роки)». Історичний архів, вип. 9, 2012, c. 41-7.

Ковтун, Альбіна. Семантична деривація в релігійній лексиці української мови. Чернівці: Технодрук, 2018. 
Колоїз, Жанна. «Біблійна алюзія як засіб вираження авторської інтенції в романі В. Шкляра „Залишенець. Чорний Ворон”». Науковий вісник Чернівещького університету. Романо-слов'янський дискурс, вип. 659, 2013, с. 3-9.

Косик, Володимир. Україна під час Другої світової війни. 1938-1945. Переклад з франц. Р. Осадчука. Київ - Париж - Нью-Йорк - Торонто, 1992.

Космеда, Тетяна. «Актуальні процеси мовлення чи „мовний смак” української сучасності». Мовознавство, № 2, 2014, с. 44-55.

Коць, Тетяна. «Оцінність як семантико-стилістична категорія публіцистичного стилю». Українська мова, № 4, 2016, с. 78- 86.

Коць, Тетяна. Публіщистичний стиль в українській літературній мові кінця ХІХ початку XXI cm.: нормативно-аксіологічний аспект. Дис. ...докт. філол. наук: 10.02.01. Київ, 2019.

Коч, Наталя. «Інтертекстуальність роману Ліни Костенко „Записки українського самашедшого"». Наукові записки Бердянського державного педагогічного університету. Серія: Філологічні науки, вип. 3, 2014, с. 211-20.

Масенко, Лариса. Мова радянського тоталітаризму. Київ: Кліо, 2017.

Словник української мови, за ред. І. К. Білодіда. В 11 т. Київ: Наукова думка, 1970-1980.

Словник фразеологізмів та паремій Чернівеччини, уклад.: Г. Кузь, Н. Руснак, М. Скаб, Л. Томусяк. Чернівці, 2017.

Фразеологічний словник української мови, уклад. В. М. Білоноженко та ін. Київ: Наукова думка, 2003.

Шкрумеляк, Михайло. Тлумачний словник-довідник гуцульських говірок. ІваноФранківськ, 2016.

\section{References}

Benkendorf, Hennadii. "Khrystos i khrystyianstvo. Semantyka ta prahmatyka kontseptiv u movi totalitarnykh partii". NaUKMA Research Papers, iss. 34, 2004, pp. 15-21.

Bohdan, Svitlana. "Biblical Exspressions in a System of an Epistolary Selfportrait of Lesia Ukrainka". Volyn philological: text and context, iss. 17, 2014, pp. 15-36.

Vasylchuk, Mykola. Ukrainska vydavnycha sprava u Kolomyi (druha polovyna XIX-XX st.). Kolomyia: Vik, 2012.

Vergalyuk, Maria. "Functions of biblical phraseologisms in artistic texts". Scientific Herald Yuriy Fedkovych Chernivtsi National University. Series: Romano-Slavonic Discourse, iss. 812,2019 , pp. 36-40.

Veselova, Natal'ja. Ironija v politicheskom diskurse. PhD Thesis. Nizhnij Novgorod, 2003.

Halaur, Svitlana. "Biblical expressions - regulatemes in modern ukrainian prose". Scientific Herald Yuriy Fedkovych Chernivtsi National University. Series: Romano-slovianskyi dyskurs, iss. 812, 2019, pp. 73-7.

Dziuba, Ivan. Trydtsiat rokiv zi Stalinym. Piatdesiat rokiv bez Stalina. Kyiv: Krynytsia, 2003.

Zhaivoronok, Vitalii. "Bibleizmy”. Ukrainska mova: entsyklopediia, edited by V. M. Rusanivskyi, and 0. 0. Taranenko. Kyiv, 2007, pp. 48-9.

Kapitan, Larysa. "Rosiiska pravoslavna tserkva yak znariaddia utverdzhennia monokonfesiinosti Zakarpattia (povoienni roky)”. Istorychnyi arkhiv, iss. 9, 2012, pp. 41-7.

Kovtun, Albina. Semantychna deryvatsiia v relihiinii leksytsi ukrainskoi movy. Chernivtsi: Tekhnodruk, 2018.

Koloiz, Zhanna. "Bibliina aliuziia yak zasib vyrazhennia avtorskoi intentsii v romani V. Shkliara "Zalyshenets. Chornyi Voron"”. Scientific Herald Yuriy Fedkovych Chernivtsi National University. Series: Romano-Slavonic Discourse, iss. 659, 2013, pp. 3-9.

Kosyk, Volodymyr. Ukraina pid chas Druhoi svitovoi viiny. 1938-1945. Translated by Roman Osadchuk. Kyiv - Paryzh - Niu-York - Toronto, 1992.

Kosmeda, Tetiana. "Actual Current Speech Practices or "language taste" of the Ukrainian Modernity". Movoznavstvo, no. 2, 2014, pp. 44-55. 
Kots, Tetiana. «Axiology as Semantic and Stylistic Category of Journalistic Style». Ukrainian Language, no. 4, 2016, pp. 78-86.

Kots, Tetiana. The journalistic style in the the Ukrainian literary language of the late nineteenth and early twenty-first centuries: the normativeaxiological aspect. Doctoral Thesis. Kyiv, 2019.

Koch, Natalia. "Intertekstualnist romanu Liny Kostenko "Zapysky ukrainskoho samashedshoho"'”. Scientific Papers of Berdiansk State Pedagogical University. Series: Philological sciences, iss. 3, 2014, pp. 211-20.

Masenko, Larysa. Mova radianskoho totalitaryzmu. Kyiv: Klio, 2017.

Slovnyk ukrainskoi movy, edited by I. K. Bilodid. 11 vols. Kyiv: Naukova dumka, 1970-1980.

Slovnyk frazeolohizmiv ta paremii Chernivechchyny, edited by H. Kuz, N. Rusnak, M. Skab, L. Tomusiak. Chernivtsi, 2017.

Frazeolohichnyi slovnyk ukrainskoi movy, edited by V. M. Bilonozhenko and all. Kyiv: Naukova dumka, 2003.

Shkrumeliak, Mykhailo. Tlumachnyi slovnyk-dovidnyk hutsulskykh hovirok. Ivano-Frankivsk, 2016.

Стаття надійшла до редколегії 22.02.2021 